\title{
Model of Entrepreneurship for People with Disabilities
}

\author{
S Eko Putro Widoyoko ${ }^{1,{ }^{*}}$, Budi Setiawan ${ }^{1}$, Khabib Sholeh $^{1}$ and Muh. Ibnu Shina ${ }^{1}$ \\ ${ }^{1}$ Universitas Muhammadiyah Purworejo, Purworejo, Indonesia
}

\begin{abstract}
Persons with disabilities are often regarded as unproductive citizens, unable to carry out their duties and responsibilities so that their rights are ignored. Indonesia is a country that has various risks of disability due to various causes, such as prolonged armed conflict, chronic diseases and natural disasters in various areas such as earthquakes, flash floods, landslides and so on. People with disabilities are under-represented in the workforce, often facing discrimination by employers, and often not served and protected effectively. To support the active participation of people with disabilities in society and the economy, this paper aims to explore the role of entrepreneurs with disabilities and the entrepreneurship model of people with disabilities in the study area. We explore entrepreneurial activities between people with disabilities, theoretical foundations, provide entrepreneurial benefits and challenges for people with disabilities, and propose policy recommendations for models of entrepreneurship development with disabilities. Development of entrepreneurship programs for people with disabilities is needed to combat these barriers, promote empowerment and facilitate economic independence for people with disabilities. This model includes courses on how to write business plans, one-on-one business guides, technical assistance, new business grants, and assistance from business incubators.
\end{abstract}

\section{Introduction}

The number of people with disabilities in the world reaches $15 \%$ of the world's population (WHO, 2011). Persons with disabilities who are referred to as disabled people on a daily basis are often regarded as unproductive citizens, unable to carry out their duties and responsibilities so that their rights are ignored. Disability is a reality for many people globally and has been identified by the World Health Organization (WHO) as a challenge faced by all nations, for two main reasons, aging of the world's population and increasing rates of chronic diseases [1]. The situation in Indonesia reflects this global reality, with more and more people suffering from some form of disability and is expected to increase over time. One of the most significant social impacts of disability is its impact on the economy; in particular the lower level of participation in the workforce [2].

\footnotetext{
${ }^{*}$ Corresponding author: ekoputro@umpwr.ac.id
} 
In many countries there is a growing recognition that one of the opportunities to increase the participation of workers with disabilities is entrepreneurship and entrepreneurship [3, 4, $5,6]$. It is said that entrepreneurship can lead to breaking down the barriers faced by people with disabilities and giving them opportunities that are traditionally seen as impossible or unattainable given the constraints of finding work.

Over the past two decades entrepreneurship has been promoted as a poverty alleviation strategy for unemployed and underemployed groups of people with disabilities [7]. From the results of various studies, people with disabilities have an interest in entrepreneurship and entrepreneurship [8].

From the explanation above, entrepreneurship can be said to be the key to increasing labor participation, economic development, and social inclusion for persons with disabilities, therefore discussion on entrepreneurship for people with disabilities must be considered as opportunities for Indonesia. This paper will serve as an opportunity to explore how entrepreneurship can be part of the solution to increasing the role of disability in economic growth, both as entrepreneurs and as workers.

\section{Methodology}

This research uses descriptive-qualitative research type. Descriptive research is research that aims to accurately describe certain situations, phenomena, or groups, or to determine the frequency of certain relationships between phenomena and others in society.

In this study, data collection was carried out in several ways, as follows: a) Literature Study, which was done by collecting data from a number of references relating to disability, population, entrepreneurship, etc., b) Field Study, to obtain primary data with using data collection techniques such as observation, in-depth interviews, and documentation.

\section{Result and Discussion}

\subsection{Disability in Indonesia}

The number of people with disabilities in Indonesia is $6,008,661$ people. Of these, around $1,780,200$ people were persons with visual disabilities, 472,855 people with disabilities who were deaf, 402,817 people with disabilities / intellectuals, 616,387 people with disabilities, 170,120 people with disabilities who were difficult to take care of themselves, and around 2,401,592 people with multiple disabilities. The largest percentage of people with disabilities in Indonesia are people with multiple disabilities, $42.71 \%$ (Fig. 1). 


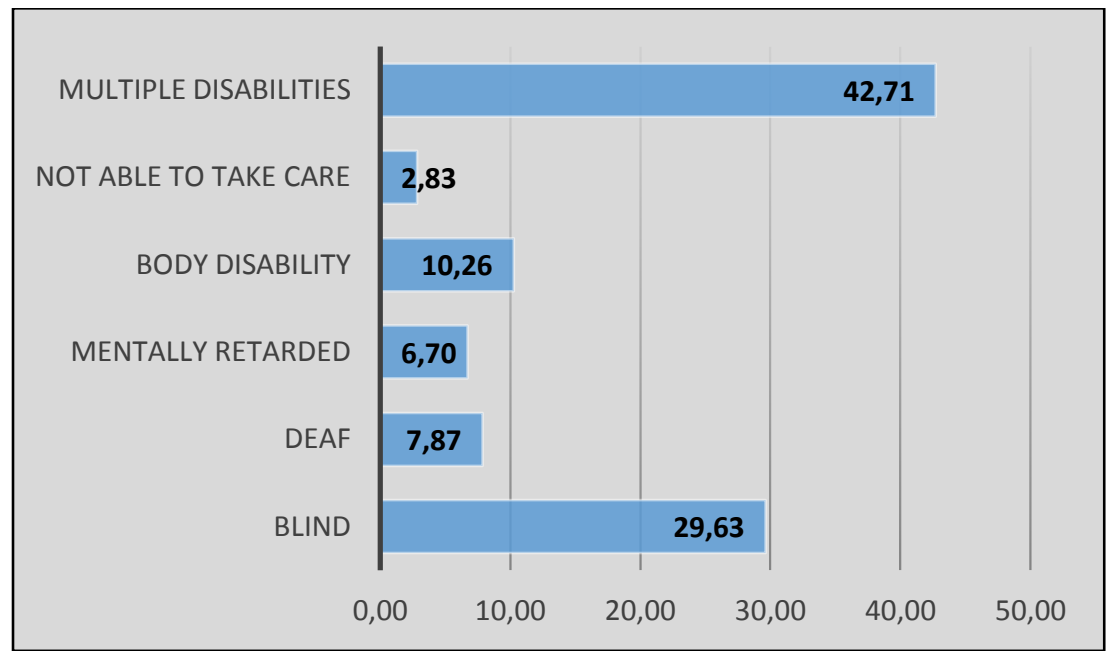

Fig. 1. Percentage of Type of Disability in Indonesia

(Source: Susenas, BPS, 2012)

The percentage of people with disabilities is almost evenly distributed between villages and cities. In villages, people with disabilities are more than in cities from year to year (Fig. 2). Greater disability rates in rural areas illustrate that people with disabilities have more difficulties in obtaining income or employment opportunities because of the small types of jobs in rural areas that can be accessed accessed by persons with disabilities.

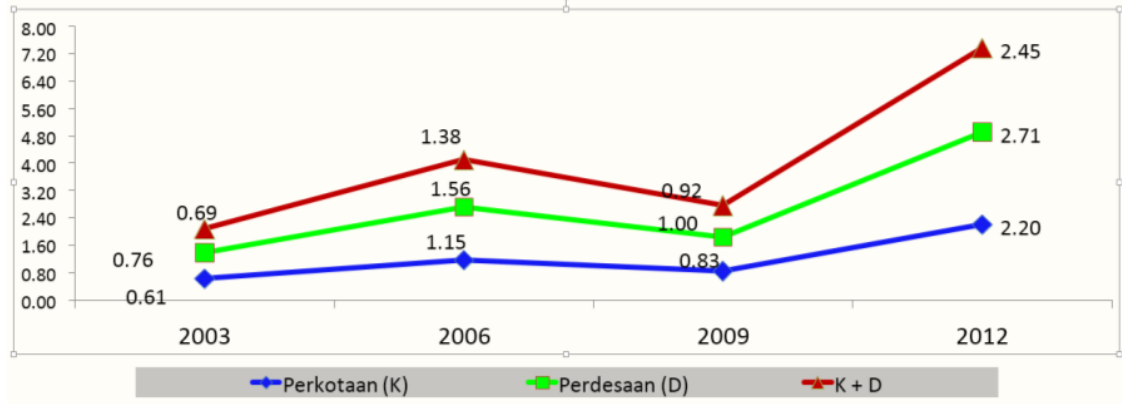

Fig. 2. Percentage of people with disabilities based on villages and cities (Source : Susenas BPS, 2003, 2006, 2009, 2012)

In Indonesia, people with disabilities who have jobs only $25.6 \%(74.4 \%)$ do not work, with the largest jobs as farmers (39.9\%) and laborers (32.1\%), only $8.5 \%$ with disabilities who is a trader or entrepreneur. The majority of people with disabilities do not work because of the lack of skills and education. While for people with disabilities who work mostly work in the informal sector and with very limited wages [9]. With this condition people with disabilities live in poverty, high dependency and marginalization [10]. On the one hand, they are often marginalized from the mainstream of employment and labor market opportunities due to physical limitations and skills [11].

\subsection{The importance of entrepreneurship for disability}

The development of the entrepreneurship model is an important consideration, because entrepreneurship will prove to be a valuable pillar to overcome this important problem. This is because the participation of the labor force for people with disabilities has declined over 
the past decade, especially those with severe, severe and moderate disabilities $[12,13,14]$. This condition occurs even though investment in career development, employment services, has been carried out by the Ministry of Social Affairs through the Loka Bina Karya program. This means entrepreneurship is a strategy that is expected to increase labor force participation, involvement in economic growth of persons with disabilities.

Information on entrepreneurship among people with disabilities in Indonesia is very little. On the one hand, in some areas, such as in Klaten Regency, it is considered to have succeeded in developing entrepreneurship for persons with disabilities. The Klaten Disabled Persons Association (PPCK) continues to encourage the independence of the disabled. One of them is to equip diffables with entrepreneurial skills. Until now, there are around 2,300 people with disabilities who have businesses. the number is around $20 \%$ of the total disability in Klaten as many as 11,586 people. (Okezone, 25 November 2016). The success of encouraging entrepreneurship is also inseparable from the regulations that have been issued by the local government through the Regional Regulation (Peraturan Daerah/Perda) Number 2 of 2011 concerning the Equality of Disabled Independence and Welfare.

Entrepreneurial growth in people with disabilities is also in line with the findings of information in various countries. The Australian Bureau of Statistics (2013) report states that people with disabilities are more likely to run their own business than those who are not disabled, with a ratio of 11.6 to $8.2 \%$, respectively. The Australian Government has also established a New Enterprise Incentive Scheme (NEIS) that allows disabled individuals access to training and support services through Disability Employment Services [15]. Similar to Australia, a study examining the activities of entrepreneurs with disabilities in $13 \mathrm{EU}$ member states found that higher levels of participation existed for those with disabilities [16]. South Korea has more than 2.6 million people registered as disabled with $99.5 \%$ of those in the labor force [5]. Hwang \& Roulstone (2015) also found 915,217 economically active disabled people in South Korea, 388,241 identified as self-employed.

\subsection{Development of Entrepreneurship Models for Disability}

As discussed earlier, the current Indonesian government policy does offer support for interested individuals who are interested in being involved in entrepreneurship. Other policy platforms have been identified that will lead to increased success. By applying a biopsychosocial model approach to disability, we recommend a disability entrepreneurship development model through the following initiatives:

1) Awareness raising

The first and very important step for people with disabilities is to increase awareness of entrepreneurial activities. This needs to be done because of lack of awareness about unemployment and small business ownership among those who face disability.

2) Entrepreneurship skills training

The expansion of the existing small business start-up training program is another policy recommendation that can lead to greater interest, effort, and success in the small business that just started. Expanding access to existing programs and bringing new technologies to provide training that supports disability and accommodates lower levels of education is the key. Programs can also be adjusted for special hearings with certain disabilities. Business training services and support that is currently inaccessible to people with disabilities can be expanded and adjusted to be inclusive of people with disabilities. With this model, people with disabilities will receive training in starting a business in a context that supports and understands to face increasing challenges.

3) Access to financial support

The biggest obstacle for every start is accessing capital. This obstacle is even more pronounced for people with disabilities, because people with disabilities have less work 
experience, education and savings. Some policy options for accessing financial support are increased participation in venture capital activities, and business networks

\section{Conclusion}

This paper examines the state of entrepreneurship of people with disabilities in Indonesia and several international studies, which have examined ways to improve policies to increase opportunities for disabilities to be involved in entrepreneurship. The development of the entrepreneurship model is recommended using a biopsychosocial model approach.

\section{References}

1. OECD. Sickdiswork: Breakbar. Stock., Swed: OECD Pub. (2010).

2. WHO. Wor. Rep. Dis.. Retrieved from http://www.who.int/disabilities/world_report/2011/report/en/. (2011).

3. Gouskova, E. Selfempl among peowitdis: Evifro curpopsur. Retrieved from SSRN 2175687. (2012).

4. Halabisky, D. EaE- Eforpwithdis. Surrey, UK: OECD Pub. (2014).

5. Hwang, S. K., \& Roulstone, A. ED? Tsapfordispmic SoKo. Dis. and Soc., 30(1), 114129. (2015).

6. Jones, M. K., \& Latreille, P. L. Das: EfUK. App. Eco, 43(27), 4161-4178. (2011)

7. Blanck, P. D., Sandier, L., Schmeling, J., \& Schartz, H.. Tewof ewith dis: PsofeninIo. Iowa Law Rev., 85, 1583 at 1649. (2000).

8. Arnold, N. and Ipsen, C. 'SEP: CTD', J Dis. Po. Stu., 16, 2, 115-122. (2015).

9. Halimatussadiah, A., Agriva, M., Nuryakin, C. PWD and LF in Indonesia: A Pre. St. LPEM-FEUI Wor. Pap. 003: ISSN 2356-4008. p. 1-14. (2015)

10. ILO. Dis. Int. Lab. Off. (2007)

11. ILO. (2007) FDWW. Int. Lab. Off. (2007)

12. Parker Harris, S., Caldwell, K., \& Renko, M. Eaon: SS vs I. J Soc Work in Dis. \& Re, 13(4), 317-349. (2014)

13. Schumpeter, J. A. (2000). Easi. Ent: TSocSciView, 1, 51-75. (2000)

14. Athanasou, Tidsew, Aus. Jour. Car. Dev. 23, (2) (2004)

15. JobAccess. NEIS. Retrieved from http://www.jobaccess.gov.au/content/new-enterpriseincentive-scheme. (2015)

16. Paga' n, R. SE PWD: EforEur. Dis. and Soc, 24(2), 217-229. (2009). 